\title{
Lichenometry dating of coseismic changes to a New Zealand landslide complex
}

\author{
William B. Bull \\ Geosciences Department, University of Arizona, Tucson, AZ, U.S.A.
}

\begin{abstract}
Lichenometry is a surface-exposure-dating procedure that complements traditional trench-and-date stratigraphic studies of earthquakes. Lichens on the surficial blocks of a slump in the Seaward Kaikoura Range, South Island, New Zealand provide precise, accurate ( \pm 2 years) dating of 20 post-landslide rockfall events. The coseismic character of these rockfall events is apparent when ages of lichen-size peaks are compared with dates of historical earthquakes. Most local prehistoric lichen-size peaks are synchronous with peaks at other lichenometry sites in a $20000 \mathrm{~km}^{2}$ region. Lichenometry may be the best paleoseismic tool for describing the extent and intensity of seismic shaking caused by prehistoric earthquakes, and for dating earthquakes generated by concealed thrust faults and subduction fault zones.
\end{abstract}

Key words earthquakes - lichens - paleoseismology-Southern Alps

\section{Introduction}

Stratigraphic studies made in trenches excavated across fault scarps continue to be important for paleoseismology.

Advantages of the trench-and-date approach include:

1) Identification of the fault responsible for a specific surface-rupture event.

2) Confirmation of seismic slip as revealed by liquefaction disturbance and offset strata.

3) Constraint of times of prehistorical earthquakes, usually by radiocarbon dating.

4) Estimates of offset of strata and buried stream channels that can be used to estimate slip rates.

Trenching along the plate-bounding Alpine Fault of New Zealand has provided age estimates

Mailing address: Dr. William B. Bull, Geosciences Department, University of Arizona, Tucson, AZ, 85721, USA; e-mail: Bill@ActiveTectonics.com for several prehistoric (before 1840 A.D. in New Zealand) earthquakes (Cooper and Norris, 1990; Yetton, 1998; Wells et al., 1999).

Trench-and-date paleoseismology has several drawbacks. Not all faults have accessible scarps including thrust faults in the cores of folds and submarine faults, and faults beneath large cities. Earthquakes can not be radiocarbon dated directly, because stratigraphic samples of organic material were created and deposited either before or after a specific earthquake. Earthquakes may occur during times of nondeposition at a trench site. Trench studies are expensive, time consuming, and provide little information about the extent and intensity of seismic shaking.

Lichen dating of regional coseismic landslide events (Bull, 1996a; Bull and Brandon, 1998) complements stratigraphic dating of earthquakes. Advantages of this new approach to paleoseismology include:

1) Estimation of the time of the earthquake itself.

2) Precision and accuracy of dating that is \pm 10 years or better.

3) Ability to make maps depicting patterns of seismic shaking for prehistorical earthquakes 
that are as good as Mercalli intensity maps for historical earthquakes.

Deficiencies of earthquake-lichenometry studies include inability to measure amounts of coseismic slip, possible lack of suitable slow growing crustose lichens in a study area, and possible lack of lichens older than 300 years at some sites. Lichens older than 1000 years are rare. However, unstable and rapidly changing hillslopes of tectonically active mountains favor detection of regional rockfall events generated by distant earthquakes.

\subsection{Purpose and scope}

This article summarizes a surface-exposuredating approach to paleoseismology that avoids the problems associated with radiocarbon dating of organic matter that is younger than 300 years. The purpose is to illustrate the quality and diversity of paleoseismologic information that can be obtained from a lichenometry study of one landslide. Each new site in the New Zealand study region uses the existing calibration of lichen growth, and is tied into the regional database. Lichen-sizes at this landslide document more than 20 historic and prehistoric earthquakes; all done at very low cost and in a time span of only 2 days of field and computer time. This efficiency was possible because of a database of 35000 lichen-size measurements at 95 sites in the Southern Alps. The scope of this article also includes a summary of reconnaissance methods and data-collection procedures.

\subsection{The Seaward Kaikoura Range}

The landscape of the Seaward Kaikoura Range (figs. 1 and 2) is dynamic because of unusually fast uplift rates, easily eroded rocks, and large rainfall events. Mean annual precipitation is about 1.5 to $2 \mathrm{~m}$. Daily rainfall amounts can

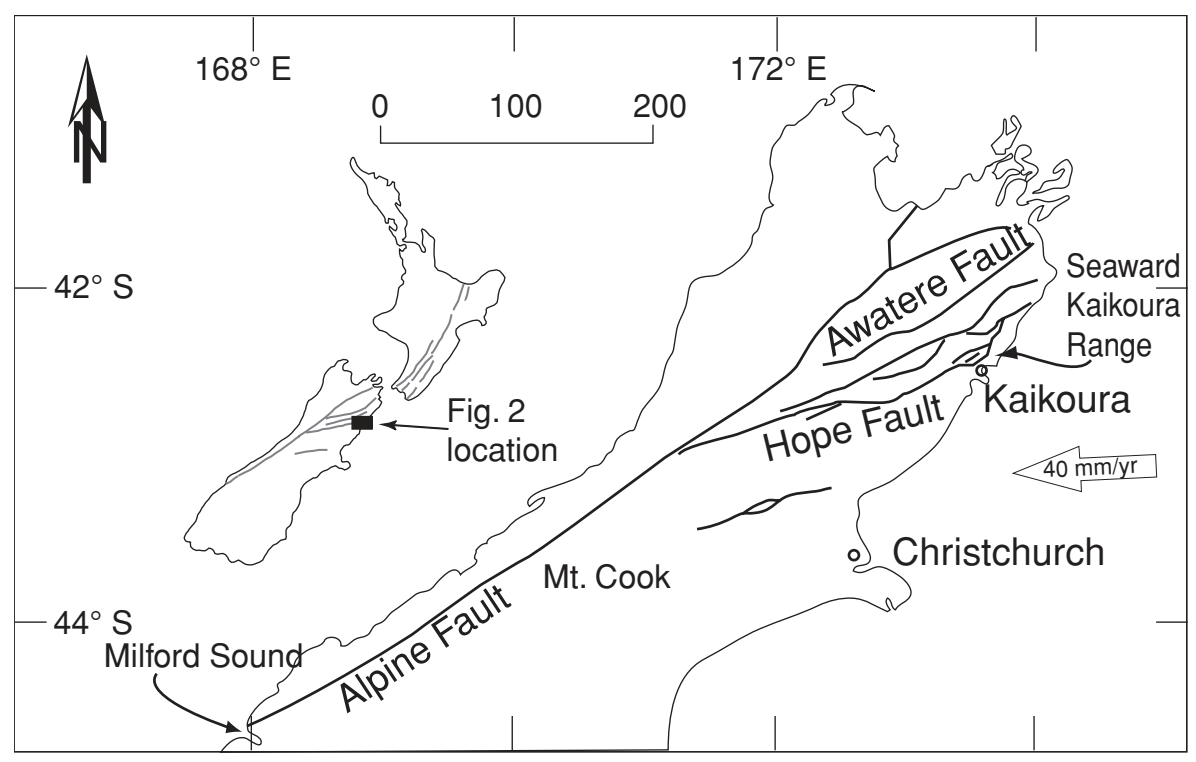

Fig. 1. Tectonic setting of landslide study area in the South Island of New Zealand. Diagonal zone of faulting is along the transpressional boundary between the Pacific and Australian plates. Plate convergence rate inside the arrow is from De Mets et al. (1994). Location of fig. 2 image is shown by the rectangle on the inset map showing the North Island and South Island. 


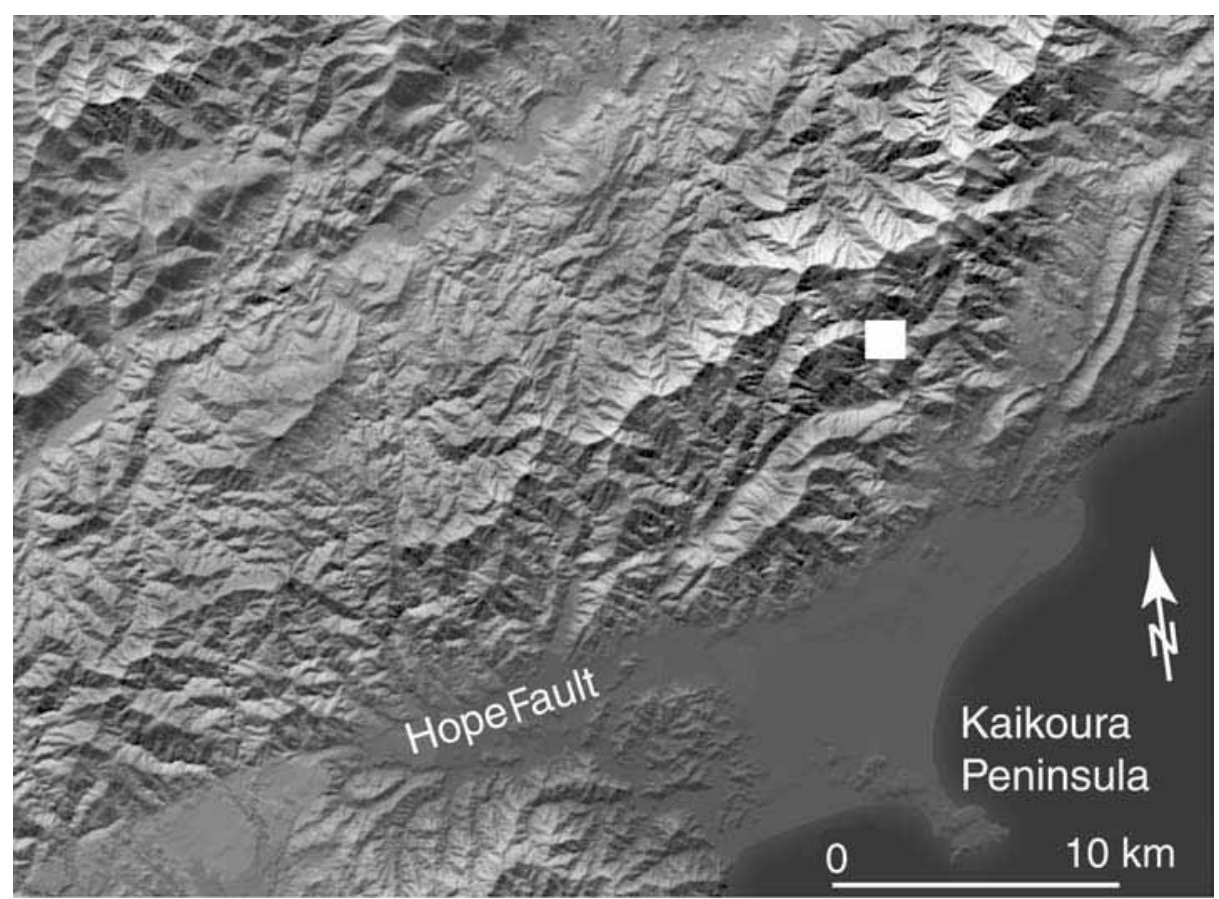

Fig. 2. The Hope Fault stands out on this digital image because of its rapid slip rate. The Seaward Kaikoura Range rises 1500 to $2600 \mathrm{~m}$ above the Pacific Ocean. Location of the Barretts landslide is shown by the white square. Image provided courtesy of Scott Miller and Manaaki Whenua Landcare Research, New Zealand.

be large. Cyclone Alison dropped $2003 \mathrm{~mm}$ of rain on Kaikoura in $24 \mathrm{~h}$ in March 1974. Steep hillsides rise to a $2600 \mathrm{~m}$ high range crest above fairly narrow valley floors, and are underlain by highly fractured greywacke sandstone with some argillite and tuffaceous sandstone.

Uplift of the Seaward Kaikoura Range, and displacements along the fault zones of the Marlborough-Alpine Fault System, is the result of oblique convergence between the Pacific and Australian crustal plates. The Marlborough Fault System is composed of steeply-dipping, sub-parallel, right-lateral, strike-slip faults. The Hope Fault, one of the most active faults in New Zealand, bounds the southeast side of the Seaward Kaikoura Range, and major splays of the fault split the range into blocks (Van Dissen, 1989; Van Dissen and Yeats, 1991). The high angle reverse slip component of faulting de- creases to the southwest. Late Holocene horizontal slip rates are about $30 \mathrm{~m} \pm 3 \mathrm{~m} / \mathrm{ky}$, and vertical rates are 2 to $6 \mathrm{~m} / \mathrm{ky}$ (Van Dissen, 1989; Bull, 1991; Knuepfer, 1992). The southwestern end of the Hikurangi trench lies just offshore, and ocean depths exceed $1500 \mathrm{~m}$ within $10 \mathrm{~km}$ of Kaikoura Peninsula. Progressively greater tilt of older marine terraces on Kaikoura Peninsula (Ota et al., 1996) shows that offshore thrust faults continue to be active.

The potential for valley floor erosion in this humid-climate setting is such that surface uplift of ridgecrests may exceed mean mountainrange rock uplift (England and Molnar, 1990). Harold Wellman recognized this elementary dependence of terrain altitude on uplift rate. He published a credible map of uplift rates for the entire South Island based on little more than this altitude-uplift-erosion relation (Wellman, 
1979). Bull (1984, 1985) used marine-terrace remnants to infer maximum uplift rates of about $6 \mathrm{~m} / \mathrm{ky}$, estimates that are similar to Wellman's.

Erosional increase of relief causes these rising mountains to crumble instead of forming high, massive cliffs such as one might expect to form in massive plutonic rocks. Watersheds yield sediment in excess of 5000 tons $/ \mathrm{km}^{2} / \mathrm{yr}$ (O'Loughlin and Pearce, 1982; Mackay, 1984), which is equal to a denudation rate of approximately $1.8 \mathrm{~m} / \mathrm{ky}$. This is about 260 times greater than undisturbed forested basins of tectonically inactive watersheds (Costa, 1994), but only 17\% of the sediment yield measured in wetter parts of the Southern Alps (Griffiths and McSaveney, 1983) that presently receive five times the mean annual precipitation of the Seaward Kaikoura Range.

Rockfalls are the most common type of mass movement and debris slides are widespread in the Seaward Kaikoura Range. Progressive unraveling (consecutive collapse events) can shift a headscarp a kilometer upslope in only 20 to 50 years. Lichen dating of blocks on these active talus slopes provides a record of only recent historical earthquakes.

So, I searched for deeper-seated landslides such as slumps, which are rare in the Seaward Kaikoura Range. Study of aerial photos revealed only one obvious slump, a large landslide complex in the upper reaches of the Hapuku River at an altitude of $750 \mathrm{~m}$; its' location is $42^{\circ} 14^{\prime} 50^{\prime \prime} \mathrm{S} ; 173^{\circ} 40^{\prime} 10^{\prime \prime} \mathrm{E}$. The informal name 'Barretts landslide' is in accord with the name of nearby Barretts Hut.

\section{Summary of the lichenometry procedure}

Dating of coseismic landslides with lichens was developed and tested as a paleoseismology tool in the Southern Alps of New Zealand (Bull, 1996b; Bull and Brandon, 1998). The method was then exported to California (Bull et al., 1994; Bull, 1996a, 2003). Many rockfall events in the Sierra Nevada dated to times of magnitude $M_{w} 7.5$ to 8 San Andreas Fault earthquakes, some with epicenters more than $400 \mathrm{~km}$ away. The Bull-Brandon procedure also works well in aseismic regions (Bull et al., 1995).

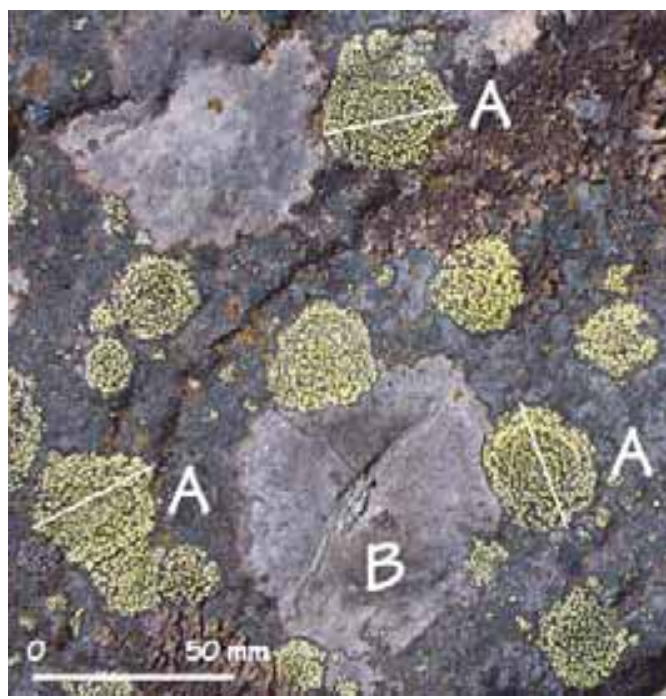

Fig. 3. Lichens growing on a rockfall block at the Barretts landslide site. A wide range of sizes for Rhizocarpon subgenus Rhizocarpon is shown. These lichens have the typical salt-and-pepper texture of most yellow rhizocarpons. Three of the largest lichens at locations A are nearly the same size; 33.46 , 34.09 , and $34.32 \mathrm{~mm}$. The white lines indicative of the longest axis maximum diameter include the black algal rim, which is part of the lichen. The top lichen is a composite of several yellow rhizocarpons, but the isolated nature of most lichens suggests that this is a first-generation community of lichens. The lichen at B is a fast-growing crustose lichen that would require a separate growth calibration.

Lichenometric studies of earthquakes begin with consecutive phases of work. The first is to determine if useful data can be obtained from the lichens that have colonized freshly exposed rock surfaces growing at a site. New rock-fall blocks tumble down hills during rainstorms and avalanches as well as during earthquakes. Crustose lichens are preferred. They grow as a tightly attached symbiotic mixture of algae and fungi on the newly exposed rock surfaces of rock-fall blocks. Slow growing yellow-green rhizocarpons (fig. 3), Rhizocarpon subgenus Rhizocarpon, commonly are favored for dating purposes because each millimeter of growth requires 2 to 30 years, varying between geo- 
graphic regions. Most New Zealand earthquakes are widely spaced in time relative to the rate of growth of Rhizocarpon subgenus Rhizocarpon, which increases in diameter $1 \mathrm{~mm}$ every 6 years. Only exposed lichens are measured so as to minimize the effects of a slightly faster growth rate in shady micro-climatic settings.

Size measurements are made with digital calipers in order to increase precision and reduce bias. The long axis of the largest lichen is measured (fig. 3 ) on each rock-fall block that has accumulated on a talus slope, hillside bench, or stream terrace. Unstable landforms such as fragile cliffs, landslides, and glacial moraines also can provide sensitive records of earthquakes. Long axes of elliptical thalli record optimal lichen growth and it is assumed that the largest lichen was the first to colonize a new rock surface. The presence of a second lichen that is nearly as large as the lichen that was measured increases ones confidence that the lichen-size measurement is indicative of the time of exposure of the rock surface. The largest lichen is quickly spotted on blocks smaller than $1 \mathrm{~m}$. Work is facilitated where more than two-thirds of the blocks have isolated instead of merged lichens and the blocks are adjacent to one another. It is important to carefully examine the thallus of the largest lichen to make sure that it does not consist of several lichens that have grown together (fig. 3), and that the margins are sufficiently sharp that replicate measurements are within $\pm 0.1 \mathrm{~mm}$. Such replicate measurements are precise $( \pm 0.6$ year of growth), so measuring lichen sizes of is a trivial source of error. Large numbers of lichen-size measurements, 100 to 1000 lichens, helps define individual lichen-size peaks and allows separation of events only 4 to 6 years apart.

Graphical portrayal of the size distribution of the largest lichen maximum diameters typically reveals a sequence of prominent histogram peaks. Determination of the ages of these lichen-size peaks requires calibration of the rate of growth, which fortunately tends to be constant over a wide range of altitudes within a particular geographic region. Preferred calibration sites are those where the date of exposure of the rock substrate is known to the day or year. Examples include tree-ring dated land- slides, rockfill dam embankments, highway, railroad, and trail cuts, landslides created by historical earthquakes, bouldery deposits of specific floods, abandoned quarries, and known times of diversions of streamflow from bouldery channels and waterfalls. Use of radiocarbon dated landforms and geomorphic processes extends a calibration data set back in time, but has much larger uncertainties for individual age estimates.

Lichen growth begins rapidly, goes through an exponentially decreasing growth phase for several decades, and then begins a prolonged uniform-growth phase. Calibration data should document each phase of lichen growth. Age estimates of lichen-size peaks at sites in the South Island of New Zealand date the time of exposure, so are the sum of colonization time, great-growth phase, and uniform phase growth.

Calibration of the growth rate for Rhizocarpon subgenus Rhizocarpon in the South Island of New Zealand is based on calibration sites such as landslides and flood deposits tables 3 and 5 of Bull and Brandon (1998) describe most of the calibration sites used in

$$
D=315.31-0.1552 t
$$

where $D$ is the mean size of a lichen-size peak (larger than the maximum great-growth peak size of $9.4 \mathrm{~mm}$ ) and $t$ is the substrate-exposure age in years. Lichen sizes were first normalized to the year 1991 A.D. to facilitate comparison with the large regional data set. In order to use eq. (2.1) each lichen size for the Barretts landslide site was reduced by $1.55 \mathrm{~mm}$ to account for the decade of post-calibration equation growth.

Plots of lichen sizes at landslide complexes rise to a broad peak and then decline. Distinct peaks that rise above this general trend record times of above-normal influx of rock-fall blocks. Not all lichen-size peaks record times of seismic shaking.

Identification of specific lichen-size peaks in probability density plots can be done with simple histograms or with the more robust decomposition of Gaussian kernel probability density plots described by Bull and Brandon (1998). These plots are constructed by converting each meas- 
urement into a unit Gaussian function and averaging the densities of lichen sizes in a probability density plot created by overlapping Gaussians. The result is analogous to a histogram, but a unit Gaussian width instead of an increment of a histogram bar represents each observation. Histogram class-interval size is replaced by a Gaussian kernel size. Lichen-size peak values are about the same for the two methods, but deconvolution of Gaussian probability density plots identifies peaks that might be hidden in standard histograms. Standard histograms are used here to illustrate their use and to test their precision and accuracy.

Lichenometric age estimates are obtained by inserting means of normally distributed lichen-size peaks into the regional equation for lichen growth. Precision of dating is estimated by comparing ages of lichen-size peaks for a specific regional rockfall event at many sites in a region. Accuracy of dating is determined by comparing lichenometric ages of regional rockfall events with dates of historical earthquakes.

The choice of an appropriate histogram class interval involves a trade-off between precision and resolution. Numerous, meaningless, small peaks are obvious noise if a class interval is too small. So one is tempted to use a large class interval. Resolution is not as good but gives the impression that the few large histogram peaks are real. This can be misleading. Merger of real peaks can create false peaks with meaningless mean lichen sizes (see fig. 10 of Bull and Brandon, 1998).

Reliability of identification of real peaks (as compared to unrealistic noise) in probability density plots increases with density of lichensize measurements. One or two measurements are worthless, but 10 to 100 measurements tightly clustered in a normal distribution supports the hypothesis of a lichen-size peak. So, density of lichen-size measurements affects choice of histogram class intervals. Sizes of lichens from a repository of rockfall blocks typically record many rockfall events with the central part of the probability density plot rising far above low tails at very small or large lichen sizes. The usual approach is to use a class interval that introduces minimal noise into the central part (high-density) part of the display of lichen-size peaks. However the tradeoff is possible spurious lichen-size peaks in the tails of the distribution where density of lichen-size measurements may be borderline.

Fortunately, the Bull-Brandon approach to paleoseismology has several ways to confirm the presence of real peaks. Real peaks also occur at many lichenometry sites in the study region because the shaking that caused the coseismic rockfalls is regional in extent. It can also be assumed that peaks are real at an individual site when they match the ages of historical earthquakes. The Barretts landslide analyses illustrate both ways to confirm real peaks. Significant peaks can also be defined as those that rise more than three standard errors above a uniform distribution of lichen sizes defined as lichens growing at a constant rate on blocks in a deposit fed by continuous rockfall events (Bull and Brandon, 1998, pp. 67-68).

\section{Application of the lichenometry procedure to the Barretts landslide complex}

A reconnaissance was made of the Barretts landslide complex to find old lichens with circular, distinct margins. The initial mass movement created a very unstable head scarp. It still has cliffs of fine-grained, strongly jointed sandstone, with joints parallel the cliff face. This cliff continues to shed rockfall blocks, especially during times of seismic shaking. Some large blocks bounce and roll to the distal parts of the Barretts landslide, smashing a few blocks along the way to create younger fresh surfaces for colonization by lichens. Blocks on unstable parts of the landslide also tip over to expose additional fresh surfaces. Most blocks on the landslide surface are in a fairly narrow size range of 0.5 to $2 \mathrm{~m}$. Initial measurements recorded a wide range of lichen sizes, which suggested a fairly complex history for the Barretts landslide site. This ability to record post-landslide-formation disturbances also applies to other surface-exposure dating methods, such as weathering rinds and cosmogenic isotopes. Stratigraphic dating methods, such as dating trees buried by a landslide, focus more on the time of the initial tectonic disturbance. 
Vegetation is sparse on this fairly young landslide that is close to treeline. A few clumps of bushes small trees are present, with patches of ferns and sphagnum moss. Large areas have few plants to shade lichens or create a fire hazard, the macro and microclimate favors Rhizocarpon subgenus Rhizocarpon, and persistent snow cover does not kill lichens.

Lichens observed along the reconnaissance route shown in fig. 4 were encouraging because the thalli were well defined and isolated (fig. 3). The head scarp has shed so much detritus that talus cones bury the cliff base. I avoided areas of young detritus, abundant trees, and sphag- num moss. The reconnaissance did not find lichens larger than $45 \mathrm{~mm}$. A distal area of surficial blocks with smooth, planar joint faces and isolated nearly circular lichens was selected to get the best possible lichen-size measurements. One could spend several days here if more measurements were needed. If this landslide were three times as old it would take a several days to get the sufficient density of measurements needed to define lichen-size peaks over a much broader range of lichen sizes.

The boundaries of small measurement areas (fig. 4) were marked and each block was examined to see if its largest lichen was of suitable

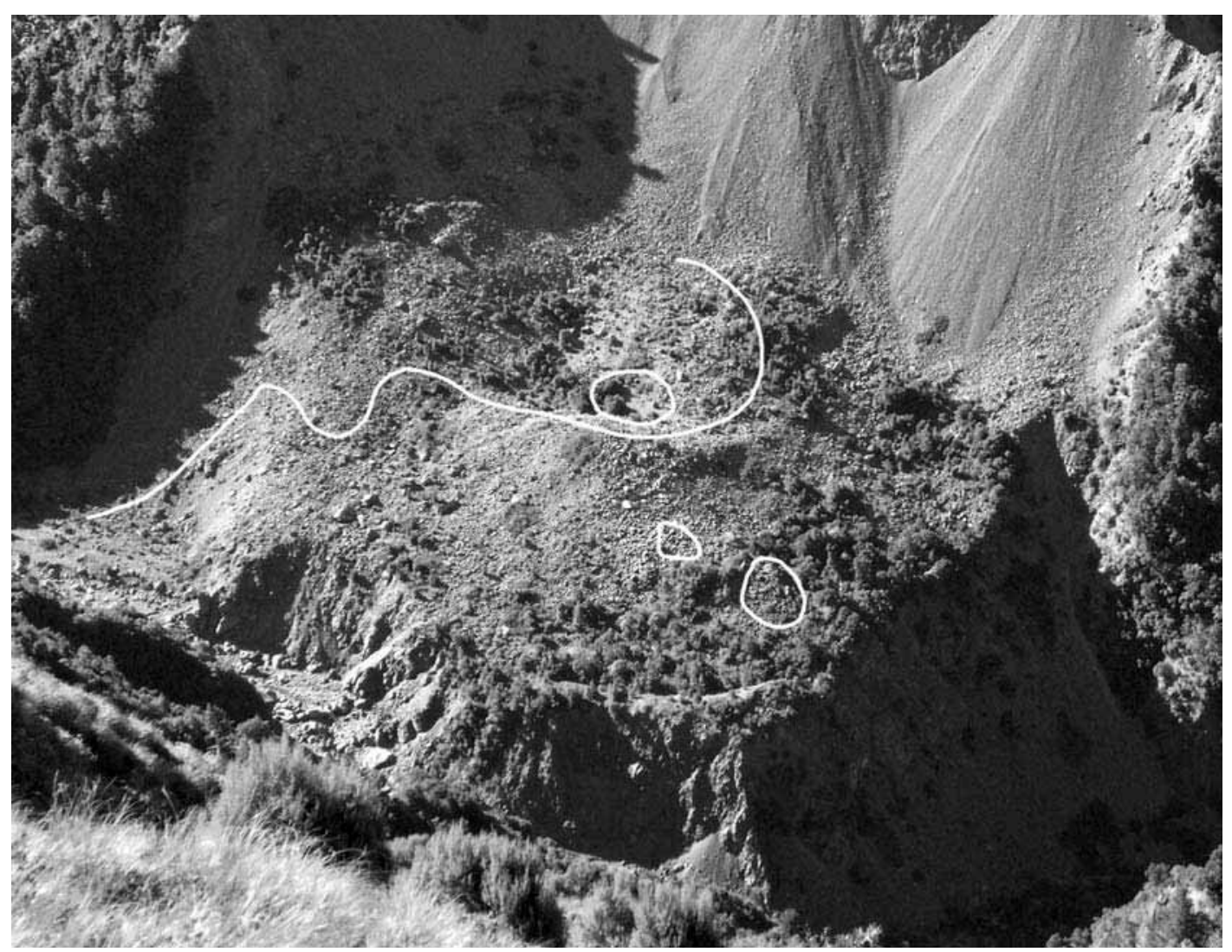

Fig. 4. View of Barretts landslide complex from Mount Stace. Unstable headscarp is partially buried with talus cones. The Hapuku River has removed portions of the toe of the landslide, thus creating younger landslides. Line shows reconnaissance route. Most lichen-size measurements were made in the enclosed areas. Barretts landslide is $18 \mathrm{~km}$ north of the town of Kaikoura in the Seaward Kaikoura Range (figs. 1 and 2). 
quality to be measured. Slight variations in color and structure of the lichens indicated that more than one section of Rhizocarpon subgenus Rhizocarpon is present here. However, that does not present a problem because we already know that all yellow rhizocarpons, with exception for Section Alpicola (not common at the lower altitudes in the Southern Alps), grow at the same rate over a wide altitude range and on a diversity of lithologies (Bull and Brandon, 1998). The reconnaissance indicated that the Barretts landslide could provide several hundred good-quality lichen-size measurements.

\subsection{Data analysis}

The sample from the Barretts landslide consists of 426 lichen-size measurements. Examination of these data with a standard histogram using a large class interval (fig. 5) reveals a fairly typical distribution of lichen sizes that rises to a maximum at about $30 \mathrm{~mm}$ and then declines.
The peak of this overall distribution is the result of several factors. Distal parts of the landslide were used for measurements because of a preference for older lichen sizes. Work in proximal parts near the active talus cones would have emphasized smaller lichens. The possibility of finding usable lichens decreases with increasing rockfall-block age. Old blocks may be broken or buried by incoming blocks, or they may be shaded by growth of bushes and trees. Some blocks have large lichens that are no longer isolated. I did not measure the largest lichen if growth of its longest axis was constrained by adjacent lichens.

The fig. 5 histogram has 11 peaks, but they rise only a short distance above coalesced background measurements. The distribution declines dramatically above a size of $45 \mathrm{~mm}$. This 1-mm class interval plot appears reasonable, but a smaller class interval might reveal more peaks. The tails of the probability density plot are weak, but the density of measurements between 19 and $46 \mathrm{~mm}$ is respectable, averaging 15 measurements per millimeter. A

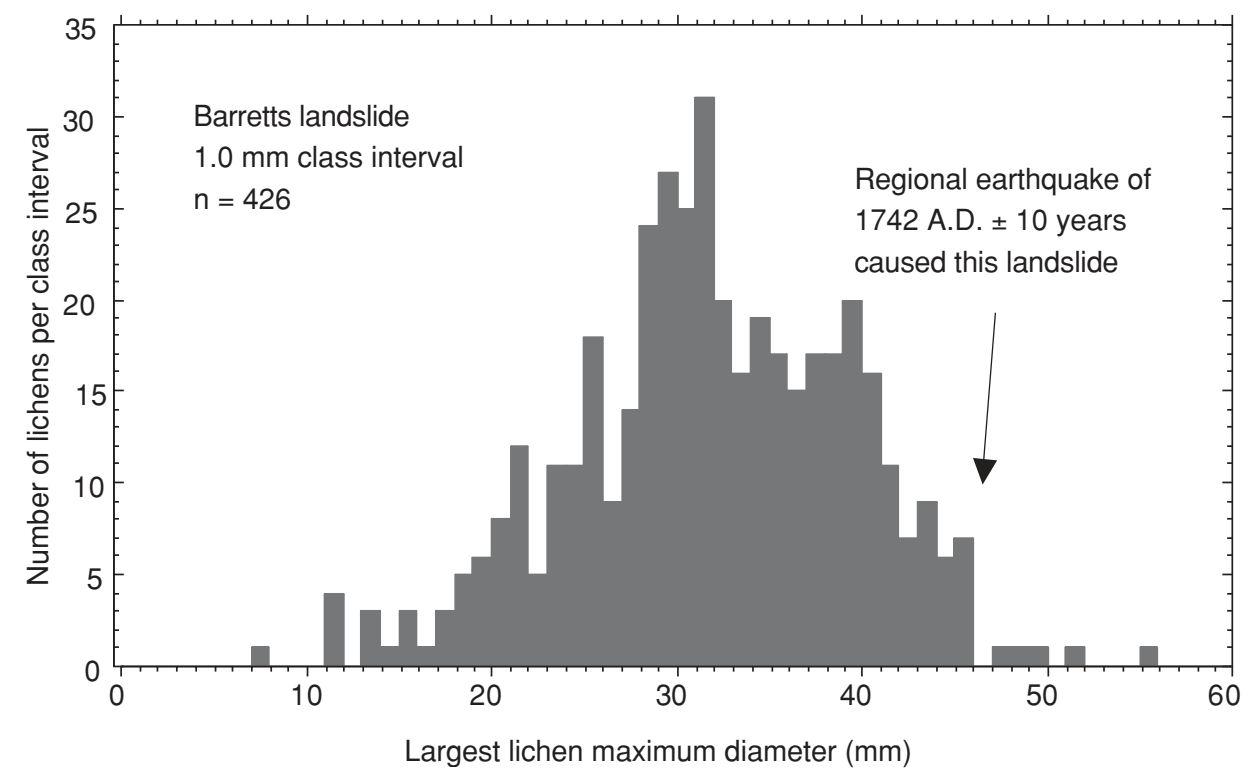

Fig. 5. Histogram of largest lichen maximum diameters for 426 rockfall blocks. 


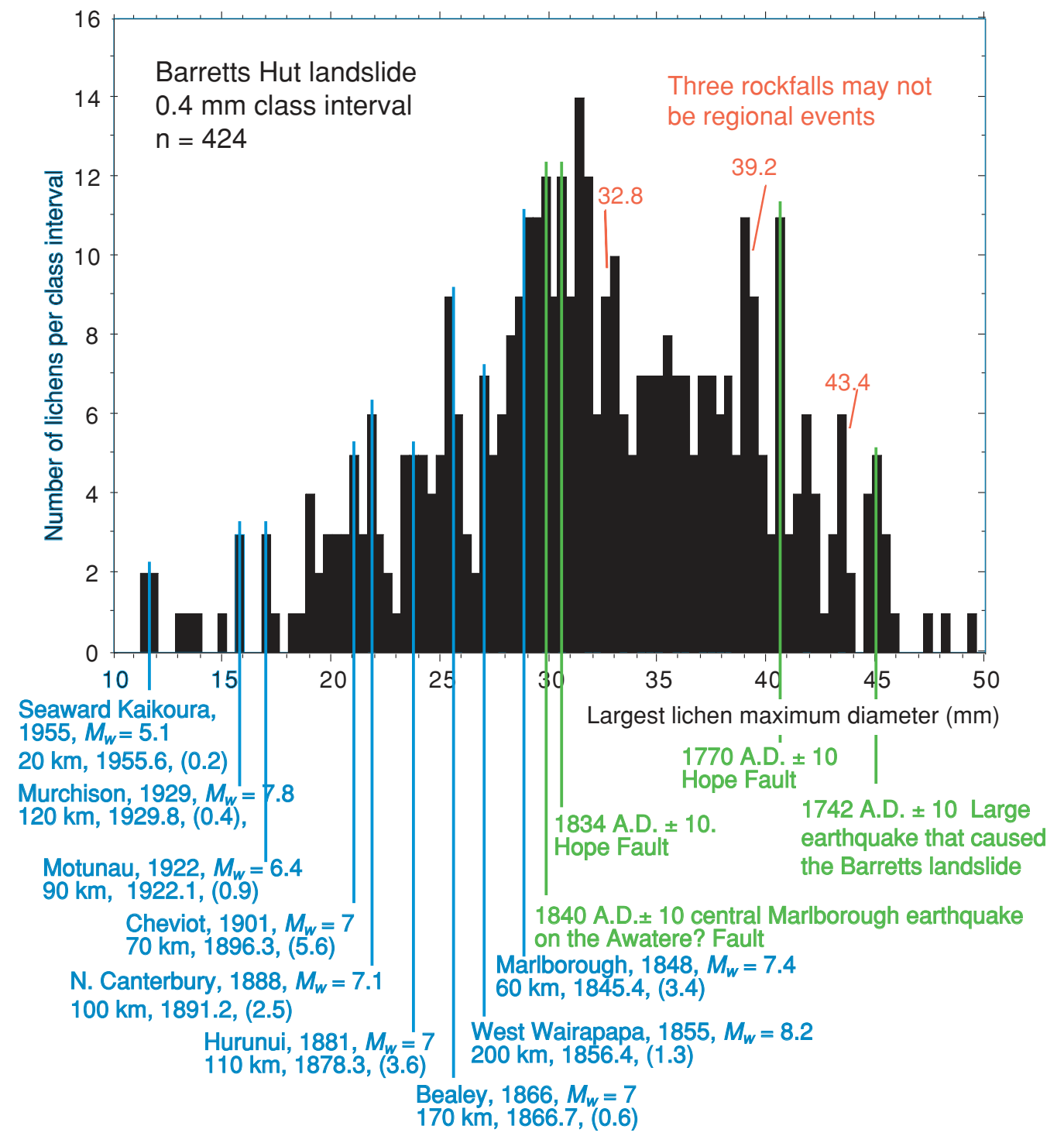

Key for historical earthquake information

Prehistoric regional rockfall events

Distance to epicenter, lichenometry date, (accuracy of date in years)

Name, year, and $M_{w}$ earthquake magnitude estimate

Fig. 6. Histogram of the largest lichen maximum diameters for 424 rockfall blocks. Lichen-size peaks with age estimates that coincide with times of historical earthquakes are shown in blue. Prehistoric earthquakes are shown in green. The time of creation of the Barretts landslide is assigned to the age of the oldest lichensize peak. 
class interval of less than $0.2 \mathrm{~mm}$ was not be used because it might have introduced spurious lichen-size peaks.

A class interval of $0.4 \mathrm{~mm}$ is used in fig. 6 , resulting in twice as many peaks than when a class interval of $1.0 \mathrm{~mm}$ was used (fig. 5). The peaks appear more isolated and stand higher above the background. Peak means have a resolution of $\pm 0.2 \mathrm{~mm}$, or \pm 1 year. But, by attempting to use a class interval of $0.4 \mathrm{~mm}$ are we introducing spurious peaks? We need to evaluate peak ages. The first step was to use eq. (2.1) to compute ages of the lichen-size peaks.
Nine of the rockfall events represented by the fig. 6 lichen-size peaks occurred since 1840 A.D., the time span of historical records. Comparison of age estimates for lichen-size peaks with historical earthquake dates allows assessment of the accuracy of lichenometric dating. Departures of rockfall event lichenometry ages from historical earthquake dates range from 0.1 to 5.6 years and average 2.0 years. Accuracy of \pm 2 years is the same as for other studies in California and New Zealand. The 1855 rockfall event coincides with the time of a North Island earthquake whose epicenter was approximately $200 \mathrm{~km}$ away. This is not unusu-

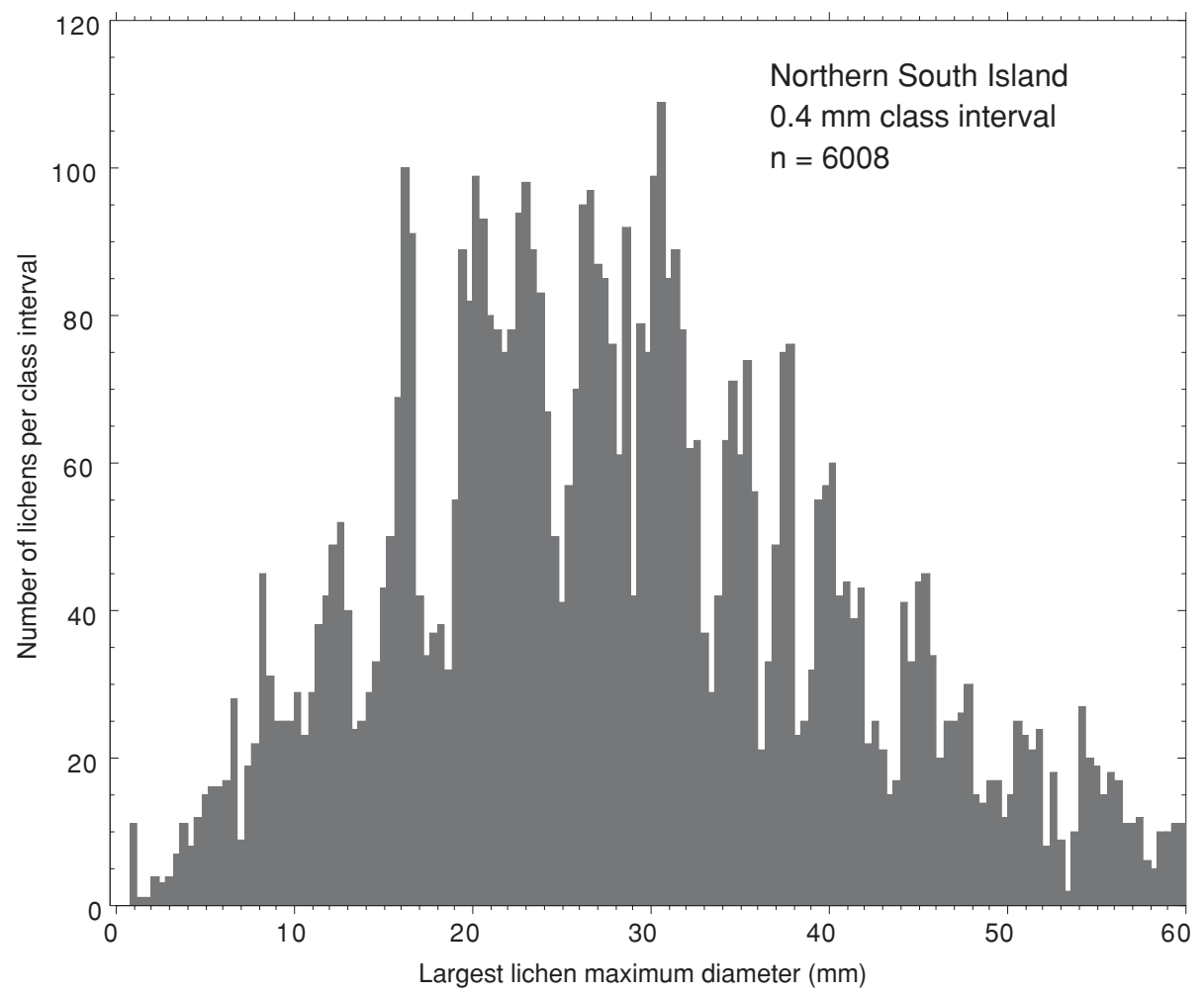

Fig. 7. Histogram of the largest lichen maximum diameters for 6008 rockfall blocks. Measurements were combined from 20 lichenometry sites in $20000 \mathrm{~km}^{2}$ of the northern part of the South Island of New Zealand underlain by quartzitic greywacke sandstone, syenite, and argillaceous greywacke sandstone. Site altitudes range from 380 to $1620 \mathrm{~m}$. Altitude and macroclimate not affect lichen growth rates as shown by the sharply defined lichensize peaks. 
al. Earthquakes with $M_{w}$ magnitudes greater than 7 can trigger rockfalls at distances of up to $400 \mathrm{~km}$ from their epicenters (Wieczorek et al., 1992; Keefer, 1994; Bull, 1996a; Wieczorek and Jäger, 1996). These results support a model that most of the lichen-size peaks larger than $29 \mathrm{~mm}$ also record coseismic rockfall events.

Each mountain range has its own mix of climatic and tectonic landslides. The combination of fractured greywacke sandstone in the tectonically active Southern Alps appears to favor earthquake-generated rock avalanches (Whitehouse, 1983) and rockfalls. Many New Zealand sites have not received an increment of new rock-fall blocks (Bull and Brandon, fig. 4) since the Inangahua $M_{w} 7.1$ earthquake of 1968 (Downs, 1995). Rainstorm induced earthflows and debris flows are important in the North Island (Crozier, 1997) and elsewhere (Nielson and Brabb, 1977; Wieczorek, 1987). In a detailed landslide inventory in Yosemite National Park, in the Sierra Nevada of California Wieczorek et al. (1992) concluded that earthquakes created only slightly more landslide volume than climatic causes. Keefer's (1994) calculations for Peru indicate that $99 \%$ of the volume of coseismic landslides is caused by earthquakes larger than $M_{w} 6$, and $92 \%$ larger than $M_{w} 7$.

Comparison of lichen-size peaks at the Barretts landslide (fig. 6) site with peaks at 20 other sites (fig. 7) underscores the regionally synchronous nature of most rockfall events. Peak size varies from site to site and not every hillslope responds to each earthquake, but peak ages are constant. The historical (post 1840 A.D.) events record times of earthquakes, so it is likely that most prehistorical peaks also were coseismic. However, the prominent 32.8, 39.2, and $43.4 \mathrm{~mm}$ lichen-size peaks shown in fig. 6 do not coincide with the fig. 7 peaks, in a region that is southeast of the Alpine Fault and north of Christchurch (fig. 1). The $43 \mathrm{~mm}$ peak is prominent southwest of Christchurch (Bull, 1996b), so its presence at the Barretts landslide site might record a distant earthquake about 12 years after creation of the landslide headscarp. Given the young age of Barretts landslide and the instability of its head scarp, one should not be surprised by nonseismic collapses at 12, 42, and 78 years after the slump created the head scarp. These events could be storm related, or perhaps just random events.

Lichen-size measurements define an isolated lichen-size peak at $45 \mathrm{~mm}$ on fig. 6 . I assume that it records the time of creation of the Barretts landslide, and the prominent peak at $45 \mathrm{~mm}$ on fig. 7 supports the impression of that Barretts slump was initially caused by an earthquake. The 5 isolated lichen sizes scattered between 45 and $60 \mathrm{~mm}$ (fig. 5) are presumed to be inherited blocks-lichens that were already growing and survived the landslide process.

\section{Potential of lichenometry for paleoseismology}

The work expended in calibrating lichen growth rates and collecting regional data sets in New Zealand (Bull and Brandon, 1998), California (Bull et al., 1994; Bull, 1996a), and Sweden (Bull et al., 1995) allows geomorphologists and paleoseismologists to visit new sites and efficiently assess ages of surficial deposits. Paleoseismologists can precisely and accurately date coseismic landslides and rockfalls at sites that are sensitive to seismic shaking. Application of the Bull-Brandon method to other tectonically active study areas will further complement stratigraphic paleoseismic studies.

Spatial variations in coseismic rockfall abundance can be used to assess patterns of prehistoric seismic shaking. Peak-size maps describe patterns of seismic shaking associated with earthquakes. Systematic regional trends depicted by peak-size maps for historical earthquakes provide the same level of information as Modified Mercalli Intensity maps (Cowan, 1991; Downs, 1995). The simple pattern of peak size associated with the $29 \mathrm{~mm}$ regional rockfall event (fig. 8) clearly suggests seismic shaking associated with a single large earthquake at about 1840 A.D. in the central part of the study region. The eastern segment of the Awatere Fault, adjacent and northeast of the maximum shaking illustrated here, ruptured in the Marlborough earthquake of 1848 (Grapes et al., 1998; Benson et al., 2001). Peak sizes for the 1840 A.D. event are anomalously low near the Conway segment of the Hope Fault (fig. 1), 


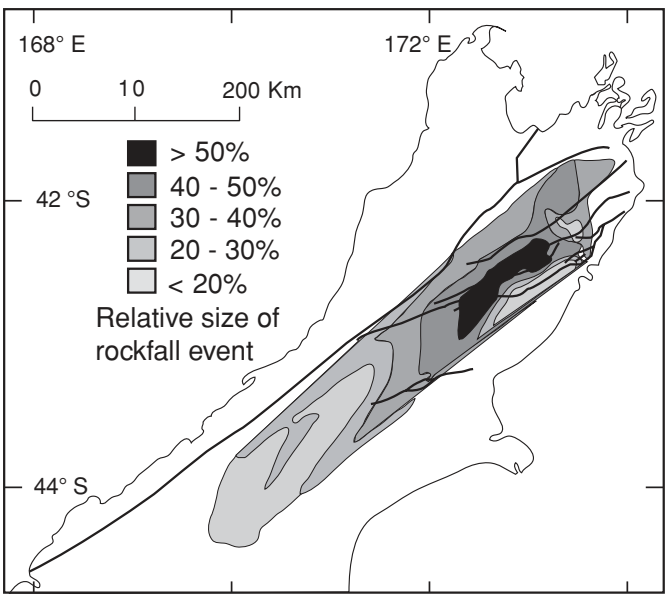

Fig. 8. Peak-size map for the $29 \mathrm{~mm}$ regional rockfall event shows one area of seismic shaking in the center of the study region. Contours show the percentage of $29 \mathrm{~mm}$ modeled peak size relative to all lichen-size measurements between 27 and $33 \mathrm{~mm}$. From fig. 23B of Bull and Brandon (1998).

probably because a Hope Fault earthquake in about 1834 A.D. had already dislodged most of the unstable blocks on steep hills.

\section{Acknowledgements}

Tim and Sally Blunt helped explore the Hapuku River and measure lichen sizes. Alastair Wright, Environment Canterbury, provided essential aerial photographs for the reconnaissance. Suggestions by Daniela Pantosti and two anonymous reviewers greatly improved the organization, content, and readability of this article.

\section{REFERENCES}

Benson, A.M., T.A. LitTle, R.J. VAn Dissen, N. Hill and D.B. TownSEND (2001): Late Quaternary paleoseismic history and surface rupture characteristics of the Eastern Awatere strike-slip fault, N. Z. Geol. Soc. Am. Bull., 113, 1071-1091.

Bull, W.B. (1984): Tectonic geomorphology, J. Geol. Educ., 32, 310-324.

BuLL, W.B. (1985): Correlation of flights of global marine terraces, in Tectonic Geomorphology: Proceedings of the 15th Annual Geomorphology Symposium, State University of New York at Binghamton, Hemelhempstead, England, edited by M. MorisawA and J. HACK (George Allen and Unwin), 129-152.

Bull, W.B. (1991): Geomorphic Responses to Climatic Change (Oxford University Press, London), pp. 326.

Bull, W.B. (1996a): Dating San Andreas Fault earthquakes with lichenometry, Geology, 24, 111-114.

Bull, W.B. (1996b): Prehistorical earthquakes on the Alpine Fault, New Zealand, J. Geophys. Res., 101 (B3), 6037-6050.

Bull, W.B. (2003): Guide to Sierra Nevada lichenometry, in Tectonics, Climate Change, and Landscape Evolution in the Southern Sierra Nevada, California, edited by G. STоск, 2003 Pacific Cell Frieds of the Pleistocene Field Trip Guidebook, appendix 8, 100-121.

Bull, W.B. and M.T. BRANDON (1998): Lichen dating of earthquake-generated regional rockfall events, Southern Alps, New Zealand, Geol. Soc. Am. Bull., 110, 60-84.

Bull, W.B., J. King, F. Kong, T. Moutoux and W.M PHILliPs (1994): Lichen dating of coseismic landslide hazards in Alpine mountains, Geomorphology, 10, 253-264.

Bull, W.B., P. Schlyter and S. BrogaArd (1995): Lichenometric analysis of the Kärkerieppe slushavalanche fan, Kärkevagge, Sweden, Geografiska Annaler, 77A, 231-240.

COOPER, A.F. and R.J. NorRIS (1990): Estimates for the timing of the last coseismic displacement on the Alpine Fault, Northern Fiordland, New Zealand, N. Z. J. Geol. Geophys., 33, 303-307.

CosTA, J.E. (1994): Water fact sheet: evolution of sediment yield from Mount St. Helens, Washington, 1980-1993, U. S. Geol. Surv. Open-File Rep. 94-313, pp. 2.

CowAN, H.A. (1991): The North Canterbury earthquake of September 1, 1888, J. R. Soc. N. Z., 21, 1-12.

CROZIER, M. (1997): The climate-landslide couple: a Southern Hemisphere perspective, in Rapid Mass Movement as a Source of Climatic Evidence for the Holocene, edited by J.A. Matthwes, D. Brunsden, B. Frenzel, B. Glaser and M.M. WeIB (Gustav Fischer Verlag), 333-353.

De Mets, C., R.C. Gordon, D.F. Argus and S. Stein (1994): Effect of recent revisions to the geomagnetic reversal time scale on estimates of current plate motions, Geophys. Res. Lett., 21, 2191-2194.

Downs, G.L. (1995): Atlas of isoseismal maps of New Zealand earthquakes, N. Z. Inst. Geol. Nucl. Sci. Monogr., 11, pp. 304

England, P. and P. Molnar (1990): Surface uplift, uplift of rocks, and exhumation of rock, Geology, 18, 1173-1177.

Grapes, R., T. LitTLE and G. Downes (1998): Rupturing of the Awatere Fault during the 1848 October 16 Marlborough earthquake, New Zealand: historical and present day evidence, N. Z. J. Geol. Geophys., 41, 387-399.

GrifFITHS, G.A. and M.J. McSAVENEY (1983): Hydrology of a basin with extreme rainfalls, Cropp River, New Zealand, N. Z. J. Sci., 26, 293-306.

KEEFER, D.K. (1994): The importance of earthquakeinduced landslides to long term slope erosion and slope-failure hazards in seismically active regions, Geomorphology, 10, 265-284. 
KNUEPFER, P.L.K. (1992): Temporal variations in latest Quaternary slip across the Australian-Pacific plate boundary Northeastern South Island, New Zealand, Tectonics, 11, 449-464.

MACKAY, D.A. (1984): Kowhai management area detritus survey, New Department of Lands and Survey, Marlborough Catchment Board Report, pp. $20+$ appendices.

Nielsen, T.H. and E.E. BRABB (1977): Slope stability studies in the San Francisco Bay region, California, Geol. Soc. Am. Rev. Eng. Geol., 3, 235-243.

O'Loughlin, C.L. and A.J. Pearce (1982): Erosion processes in the mountains, in Landforms of New Zealand, edited by J.M. Soons and M.J. SELBy (Longman Paul, Auckland), 67-79.

Ota, Y., B. Pillans, K. Berryman, T. Fujimori, T. Miyauchi, G. Berger, A.G. Beu and F.M. Climo (1996): Pleistocene coastal terraces of Kaikoura Peninsula and the Marlborough coast, South Island, New Zealand, N. Z. J. Geol. Geophys., 39, 51-73.

VAN DisSEN, R.J. (1989): Late Quaternary faulting in the Kaikoura region, Southeastern Marlborough, New Zealand, Oregon State University M.S. Thesis, pp. 72.

VAN Dissen, R.J. and R.S. Yeats (1991): Hope Fault, Jordan thrust and uplift of the Seaward Kaikoura Range, Geology, 19, 393-396.
Wellman, H.W. (1979): An uplift map for the South Island of New Zealand, and a model for uplift of the Southern Alps, in The Origin of the Southern Alps, edited by R.I. WALCOTt and M.M. Cresswell, Bull. R. Soc. N.Z., 18, $13-20$

Wells, A., M. Yetton, R.P. Duncan and G.H. Stewart (1999): Prehistoric dates of the most recent Alpine Fault earthquakes, New Zealand, Geology, 27, 995-998.

Whitehouse, I.E. (1983): Distribution of large rock avalanche deposits in the Central Southern Alps, New Zealand, N. Z. J. Geol. Geophys., 26, 271-279.

WieCZOREK, G.F. (1987): Effect of rainfall intensity and duration on debris flows in Central Santa Cruz mountains, California, Geol. Soc. Am. Rev. Eng. Geol., 3, 93-104.

WIECZOREK, G.F. and S. JÄGER (1996): Triggering mechanisms and depositional rates of postglacial slope-movement processes in the Yosemite Valley, California, Geomorphology, 15, 17-31.

WIECZOREK, G.F., J.B. SNYDER, C.S. Alger and K.A. IsSAACSON (1992): Rock falls in Yosemite Valley, U. S. Geol. Surv. Open-File Rep. 92-387, pp. 136.

Yetton, M.D. (1998): Progress in understanding the paleoseismicity of the Central and Northern Alpine Fault, Westland, New Zealand, N. Z. J. Geol. Geophys., 41, $475-483$ 
